\title{
Respon Pertumbuhan Ikan Gabus (Channa striata) terhadap Pemberian Tepung Ikan Rucah dan Udang pada Pakan Buatan
}

\author{
Ayu Agustin ${ }^{*}$, Emilda $^{1}$, Tantry Agnhitya Sari ${ }^{1}$ \\ ${ }^{1}$ Fakultas MIPA, Program Studi Pendidikan Biologi,Universitas Indraprasta PGRI \\ *email: ayuagustin304@gmail.com
}

\begin{tabular}{l} 
Article History \\
\hline Received: \\
06/01/2022 \\
Revised: \\
12/01/2022 \\
Accepted: \\
22/01/2022 \\
Kata kunci: \\
Pertumbuhan \\
ikan gabus \\
Ikan rucah \\
Udang \\
Laju \\
pertumbahan
\end{tabular}

Key word:

Growth of

snakehead fish

Trash fish

Shrimp

Growth rate

\begin{abstract}
ABSTRAK
Penelitian ini bertujuan untuk mengetahui respon pertumbuhan ikan gabus (Channa striata) dengan memberikan pakan buatan menggunakan tepung ikan rucah dan kepala udang, juga untuk mengurangi biaya pembelian pakan komersial yang mahal. Bahan campuran pakan yang dipilih merupakan alternatif lain yang dapat digunakan untuk memenuhi kebutuhan protein bagi pertumbuhan ikan setiap harinya. Adapun parameter yang diamati dalam penelitian ini meliputi panjang, berat, kelangsungan hidup, serta kualitas air. Disain penelitian disusun dengan Rancangan Acak Lengkap (RAL), dimana terdapat 4 ulangan dan 5 perlakuan. Pakan komersial yang digunakan sebagai campuran adalah pakan komersial protein rendah (PKPR) merk Eko Feed dengan taraf pemberian P0 (100\% PKPR), P1 (70\% PKPR + 30\% tepung ikan rucah), P2 (70\% PKPR $+30 \%$ tepung udang), P3 (70\% PKPR $+15 \%$ tepung ikan rucah $+15 \%$ tepung udang) dan P4 (100\% pakan komersial merk Hi Provite). Data yang didapatkan dilakukan analisis menggunakan uji ANOVA. Hasil uji ANOVA menunjukkan pemberian pakan campuran tepung ikan rucah dan udang berpengaruh nyata terhadap laju pertumbuhan panjang dan berat ikan, akan tetapi terhadap kelangsungan hidup ikan gabus tidak memiliki pengaruh nyata. Data berat dan panjang ikan kemudian dilakukan uji lanjut Beda Nyata Terkecil (BNT) untuk mengetahui perbedaan dari setiap perlakuan. Kelompok perlakuan yang paling baik pertumbuhannya adalah kelompok perlakuan P3 yang diberi tepung ikan rucah dan udang dengan konsentrasi masingmasing $15 \%$, dengan pertumbuhan berat dan panjang rata-rata adalah $6.60 \mathrm{~g}$ dan $3.10 \mathrm{~cm}$.
\end{abstract}

\begin{abstract}
This study aims to determine the growth response of snakehead fish (Channa striata) by providing artificial feed using trash fish meal and shrimp heads, as well as to reduce the cost of purchasing expensive commercial feed. The selected feed mix material is another alternative that can be used to meet the protein needs for fish growth every day. The parameters observed in this study included length, weight, survival rate, and water quality. The research design was arranged in a completely randomized design (CRD), where there were 4 replications and 5 treatments. Commercial feed used as a mixture is low protein commercial feed (PKPR) brand Eko Feed with levels of PO (100\%PKPR), P1 (70\% PKPR + 30\% trash fish meal), P2 (70\% PKPR + 30\% shrimp meal), P3 $(70 \%$ PKPR $+15 \%$ trash fish meal $+15 \%$ shrimp meal) dan P4 (100\% commercial feed brand Hi Provite). The data obtained were analyzed using the ANOVA test. The result of ANOVA test showed that feeding a mixture of trash fish meal and shrimp had a significant effect on the growth rate of fish length and weight, but on the survival of snakehead fish had no significant effect. The data on the weight and length of the fish were then carried out with the Least Signicant Difference (BNT) further test to determine the difference between each treatment. The treatment group with the best growth was the P3 treatment group which was given trash fish meal and shrimp with a concentration of $15 \%$ each, with an average weight and length growth of $6.60 \mathrm{~g}$ and $3.10 \mathrm{~cm}$.
\end{abstract}

Copyright (C) 2022 LPPM Universitas Indraprasta PGRI. All Right Reserved

\section{PENDAHULUAN}

Indonesia adalah salah satu negara yang memiliki kelimpahan keanekaragaman hayati yang tinggi. Kekayaan tersebut diantaranya yakni sumber daya perikanan di wilayah perairan tawar, pantai, dan laut. Kekayaan sumber daya perikanan ini adalah potensi alam yang sangat potensial untuk 
pengembangan usaha perikanan khususnya di Indonesia.

Ikan gabus (Channa striata) termasuk jenis ikan air tawar yang mudah ditemukan. Ikan gabus sendiri memiliki habitat di perairan yang rendah akan kandungan oksigen, seperti danau, rawa, dan juga muara sungai. Masyarakat cukup menggemari ikan ini sebab rasanya yang khas dengan daging yang tebal (Akbar, 2020). Akan tetapi, selama ini pemenuhan akan permintaan ikan gabus terbatas dan mengandalkan tangkapan dari alam. Bila ini terus menerus dilakukan, maka akan menyebabkan kepunahan.

Berdasarkan data Kementrian Kelautan dan Perikanan Republik Indonesia, pada tahun 2015 didapatkan bahwa produksi ikan gabus mencapai 6490 ton dimana hal ini mengalami peningkatan menjadi 21987 ton di tahun 2019 (KKP, 2020). Peningkatan tersebut tentu saja sangat menggembirakan, namun yang perlu dikhawatirkan adalah kelestariannya di alam. Hal ini dikarenakan mayoritas ikan gabus yang diperjualbelikan atau diproduksi adalah berasal dari alam. Oleh karena itu, untuk menghindari berkurangnya populasi ikan gabus di habitat aslinya perlu dilakukan upaya budidaya.

Budidaya ikan gabus belum banyak dilakukan karena ketersediaan pakan yang semakin sedikit di alam, dan tak jarang sulit untuk didapatkan. Dalam kegiatan budidaya, pakan adalah faktor terpenting yang diperlukan untuk mendukung perkembangan dan pertumbuhan ikan (Winarni, 2019). Pertumbuhan dapat maksimal, jika kebutuhan gizi terpenuhi. Namun harga pakan pelet komersial yang cukup mahal menjadi salah satu kendala kegiatan budidaya.

Kehidupan yang serba sulit sebagaimana kondisi saat ini, tentu masyarakat sangat menginginkan rendahnya harga pakan untuk menunjang usahanya. Faktor yang mempengaruhi seberapa berhasilnya budidaya ikan gabus di antaranya yakni pakan sebab biaya produksi sekitar 60-70\% dialokasikan untuk manajemen pemberian pakan (Muliati, 2018).

Harga pakan komersial yang tinggi salah satunya disebabkan oleh bahan baku yang masih menggunakan tepung ikan impor. Oleh karenanya, guna menyiasati mahalnya harga pakan pelet komersial maka dilakukan melalui menambahkan bahan baku lain. Tentu saja dengan bahan yang mudah didapat, harga yang lebih murah, serta mengandung nutrisi sebagai alternatif untuk menggantikan tepung ikan komersial. Salah satunya adalah dengan mencampurkan beberapa bahan limbah hasil perikanan yaitu, ikan rucah dan kepala udang.

Ikan rucah dan kepala udang merupakan hasil samping dari produksi perikanan yang jumlahnya cukup banyak dan mudah ditemukan. Seringkali ikan rucah dan kepala udang hanya menjadi limbah perikanan yang tak bernilai. Kedua jenis limbah tersebut mengandung sumber protein hewani yang dapat digunakan sebagai campuran pakan. Hasil penelitian pemanfaatan berbagai jenis ikan rucah sebagai pakan untuk kelangsungan hidup benih ikan gabus sudah dilaksanakan Kusuma dkk. (2017). Hasil penelitian ini menyatakan bahwa pemberian berbagai jenis ikan rucah yang berbeda dengan konsentrasi 50\% terbukti berbeda nyata dalam efisiensi pakan, pertumbuhan (bobot dan panjang ikan), dan kelangsungan hidup. Penelitian lainnya yang dilakukan oleh Sandri (2018), mengungkap bahwa campuran tepung kepala udang pada pakan komersial terbukti berpengaruh signifikan terhadap pertumbuhan ikan yaitu berat dan panjang ikan. Pertumbuhan terbaik pada penambahan tepung dari kepala udang memiliki persentase $75 \%$ dengan kandungan protein sebesar 49.7\%.

Pengolahan limbah ikan rucah dan kepala udang menjadi tepung dapat dijadikan alternatif untuk menggantikan bahan baku utama. Tentunya penggunaan bahan baku alternatif harus dapat dengan mudah dicerna oleh ikan, mengandung gizi tinggi, mudah diperoleh, tersedia dalam jumlah berlimpah dan tidak mengandung racun.

Berdasarkan pengamatan pada penelitian sebelumnya, sehingga penelitian kali ini akan dicoba mengombinasikan kedua bahan limbah tersebut dengan variasi konsentrasi yang berbeda pada tiap perlakuannya untuk melihat konsentrasi mana yang baik untuk menunjang pertumbuhan panjang dan berat ikan gabus.

\section{METODE PENELITIAN}

\section{a. Subjek Penelitian}

Penelitian ini dilakukan di Rumah Budidaya Ikan Air Tawar Tangerang, Banten. Ikan gabus yang digunakan sebanyak 50 ekor, berusia \pm 2 bulan dengan panjang tubuh antara $8-9 \mathrm{~cm}$. Pakan ikan komersial yang digunakan adalah $\mathrm{Hi}$ provite 781-1, pakan ikan komersial protein rendah merk Eko Feed dan pakan tambahan dari tepung ikan rucah dan tepung kepala udang.

\section{b. Prosedur Penelitian \\ 1. Tahap Persiapan Kolam Pemeliharaan}


Wadah pemeliharaan pada penelitian ini berupa boks plastik berukuran $38 \times 25 \times 25 \mathrm{~cm}$ sebanyak 5 buah. Sebelum dilakukan penelitian terlebih dahulu wadah dibersihkan. Setelah itu masing-masing boks plastik diisi air dengan kisaran tinggi $15 \mathrm{~cm}$. Pengisian air ke dalam boks menggunakan selang dan air yang digunakan berasal dari PDAM. Media air didiamkan selama 3 hari sebelum dimasukkan bibit ikan gabus.

\section{Tahap Pembuatan Pakan}

Pembuatan tepung ikan rucah dan udang yang pertama kali dilakukan adalah membersihkan bahan baku. Ikan rucah dan kepala udang yang sudah bersih kemudian direbus, dikeringkan dengan oven dan diblender tetapi untuk kepala udang tidak dilakukan perebusan. Setelah kedua bahan ditepungkan, kemudian dicampur dengan pakan komersial protein rendah (PKPR) merk Eko Feed yang sudah dihaluskan sesuai komposisi dari masing-masing perlakuan yaitu P0 kontrol (100\% pakan komersial protein rendah), P1 (70\% PKPR + $30 \%$ tepung ikan rucah), P2 (70\% PKPR + 30\% tepung udang), P3 (70\% PKPR $+15 \%$ tepung ikan rucah $+15 \%$ tepung udang), dan $\mathrm{P} 4$ (100\% pakan komersial protein tinggi). Bahan-bahan tersebut kemudian dicampur menggunakan air secukupnya dan tepung kanji sebagai perekat. Sesudah seluruh bahan tercampur, selanjutnya dilakukan pencetakan dengan cetakan manual kemudian dilakukan pengeringan dengan cara dijemur selama 5 hari.

\section{Tahap Aklimatisasi}

Pada tahap ini, ikan gabus yang digunakan memiliki panjang antara 8-9 cm/ekor. Ikan yang masih ada di dalam kemasan diletakan ke dalam air bak penampungan sementara supaya kondisi air bak dan air dalam kemasan homogen. Pelaksanaan aklimatisasi/penyesuaian ikan uji terhadap lingkungan dalam waktu 5 hari. Sebelum diberikan perlakuan ikan terlebih dahulu dipuasakan selama 1 hari sebelum dipindahkan ke dalam boks pemeliharaan. Ikan dipuasakan untuk mengosongkan lambung sehingga terjadi peningkatan konsumsi pakan harian ketika ikan diberikan makanan.

\section{Tahap Pemeliharaan}

Pelaksanaan pemeliharaan ikan selama 28 hari dengan padat tebar 10 ekor/wadah. Terdiri dari 4 ulangan serta 5 kelompok perlakuan. Selama dipelihara ikan diberikan pakan secara adlibitum sebanyak 5\%/BB/hari (Maulidin, 2016), dengan 2 kali/hari untuk frekuensi pemberian yaitu pada pukul 07.00 dan 16.00 WIB. Pemeliharaan dilakukan dengan pergantian air setiap seminggu sekali.

\section{Tahap Pengambilan Data}

Selama pemeliharaan ikan gabus akan dilakukan sampling sekali dalam 7 hari, yakni pada hari ke 7, 14, 21, serta 28 tujuannya untuk mengetahui kondisi pertumbuhan ikan. Pelaksanaan sampling dengan melakukan pencatatan bobot dan panjang dari ikan gabus. Pengambilan data sampling dilakukan secara acak sejumlah 3 ekor ikan/boks plastik.

\section{c. Analisis Data}

Berdasarkan data panjang dan bobot ikan yang didapat kemudian dihitung pertumbuhan berat mutlak, pertumbuhan panjang mutlak, pertumbuhan panjang harian, pertumbuhan berat harian, dan kelangsungan hidup berdasarkan rumus perhitungan Effendi (1997) dan Sari (2017). Data diuji dengan uji normalitas dan homogenitas, kemudian data yang normal dan homogen dilanjutkan dengan uji Anova dengan memanfaatkan bantuan Microsoft Excel 2016 dan uji lanjut Beda Nyata Terkecil (BNT), sementara analisis secara deskriptif untuk data kualitas air.

\section{HASIL DAN PEMBAHASAN}

Hasil penelitian mengenai respon pertumbuhan ikan gabus (Channa striata) terhadap pakan yang diberikan, diperoleh dengan mengukur parameter panjang $(\mathrm{cm})$, berat $(\mathrm{g})$, kelangsungan hidup, dan lingkungan media pemeliharaan. Pertumbuhan panjang dan berat harian ikan gabus selama 28 hari dijabarkan dalam Tabel 1 dan 2. Hasil yang diperoleh menunjukkan bahwa persentase pertumbuhan harian tertinggi terjadi pada perlakuan $\mathrm{P} 3$, dengan penambahan tepung ikan rucah dan udang pada pakan komersial dengan konsentrasi masing-masing $15 \%$.

Tabel 1. Pertumbuhan panjang harian ikan gabus

\begin{tabular}{cccc}
\hline Perlakuan & $\begin{array}{c}\text { Rata-rata } \\
\text { Panjang } \\
\text { Awal }\end{array}$ & $\begin{array}{c}\text { Rata-rata } \\
\text { Panjang } \\
\text { Akhir }\end{array}$ & $\begin{array}{c}\text { Panjang } \\
\text { Harian } \\
(\%)\end{array}$ \\
\hline P0 & 8.50 & 9.10 & 2.14 \\
P1 & 8.50 & 10.70 & 7.86 \\
P2 & 8.40 & 10.10 & 6.07 \\
P3 & 8.60 & 11.70 & 11.07 \\
P4 & 8.40 & 11.00 & 929 \\
\hline
\end{tabular}


Tabel 2. Pertumbuhan berat harian ikan gabus

\begin{tabular}{cccc}
\hline Perlakuan & $\begin{array}{c}\text { Rata-rata } \\
\text { Berat } \\
\text { Awal }\end{array}$ & $\begin{array}{c}\text { Rata-rata } \\
\text { Berat } \\
\text { Akhir }\end{array}$ & $\begin{array}{c}\text { Berat } \\
\text { Harian } \\
(\%)\end{array}$ \\
\hline P0 & 4.20 & 6.00 & 6.43 \\
P1 & 4.20 & 8.40 & 15.00 \\
P2 & 4.20 & 7.60 & 12.14 \\
P3 & 4.20 & 10.80 & 23.57 \\
P4 & 4.20 & 9.70 & 19.64 \\
\hline
\end{tabular}

Keterangan: P0 (100\% pakan komersial protein rendah), P1 (70\% pakan komersial $+30 \%$ tepung ikan rucah), P2 (70\% pakan komersial $+30 \%$ tepung udang), P3 (70\% pakan komersial $+15 \%$ tepung ikan rucah $+15 \%$ tepung udang), P4 (100\% pakan komersial protein tinggi)

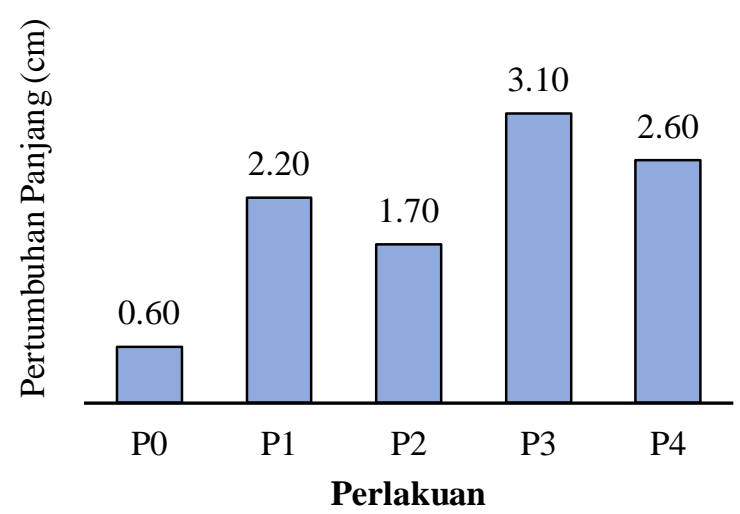

Gambar 1. Rata-rata pertambahan panjang (cm) ikan gabus selama 28 hari

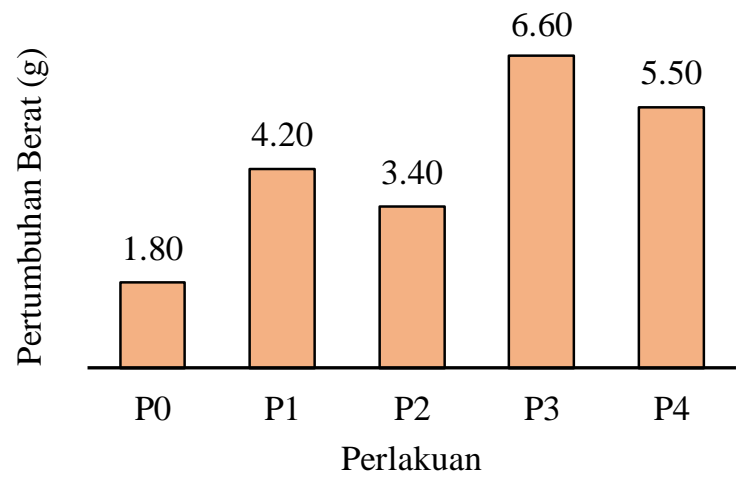

Gambar 2. Rata-rata pertambahan berat (g) ikan gabus selama 28 hari

Pertumbuhan panjang dan berat mutlak dilakukan dengan menghitung selisih rata-rata panjang/berat ikan di akhir dengan rata-rata panjang/berat ikan di awal. Hasil penelitian pertumbuhan panjang mutlak paling tinggi adalah sebesar $3.10 \mathrm{~cm}$ yaitu pada perlakuan P3 dan berat 6.60 g. Pertambahan panjang/berat mutlak ditunjukkan dalam Gambar 1 dan 2.

Data hasil pengamatan pertambahan panjang dan berat ikan gabus dianalisis dengan menggunakan analisis varian ANOVA, seperti yang ditunjukkan dalam Tabel 3 dan 4 .

Tabel 3. Analisis variansi (ANOVA) pada panjang ikan gabus

\begin{tabular}{|c|c|c|c|c|c|c|}
\hline $\begin{array}{l}\text { Sumber } \\
\text { Keragaman } \\
\text { (SK) }\end{array}$ & $\begin{array}{c}\text { Derajat } \\
\text { Bebas } \\
\text { (db) }\end{array}$ & Jumlah Kuadrat (Jk) & $\begin{array}{c}\text { Kuadrat } \\
\text { Tengah (Kt) }\end{array}$ & F Hitung & $\begin{array}{c}\text { F Tabel } \\
5 \%\end{array}$ & Notasi \\
\hline Perlakuan & 4 & 6.86 & 1.7145 & 3.305591 & 3.06 & ** \\
\hline Galat & 15 & 7.78 & 0.52 & & & \\
\hline Total & 19 & 14.64 & & & & \\
\hline
\end{tabular}

Tabel 4. Analisis variansi (ANOVA) pada berat ikan gabus

\begin{tabular}{lrrrrrr}
\hline $\begin{array}{c}\text { Sumber } \\
\text { Keragaman } \\
\text { (SK) }\end{array}$ & $\begin{array}{c}\text { Derajat } \\
\text { Bebas } \\
(\mathrm{db})\end{array}$ & Jumlah Kuadrat $(\mathrm{Jk})$ & $\begin{array}{c}\text { Kuadrat } \\
\text { Tengah } \\
(\mathrm{Kt})\end{array}$ & F Hitung & $\begin{array}{c}\text { F Tabel } \\
5 \%\end{array}$ & Notasi \\
\hline Perlakuan & 4 & 27.61 & 6.902 & 3.679104 & 3.06 & $* * *$ \\
Galat & 15 & 28.14 & 1.88 & & & \\
\hline Total & 19 & 55.75 & & & & (Fhitung $>$ F Fabel)
\end{tabular}


Berdasarkan kesimpulan yang diperoleh dari hasil uji ANOVA menunjukkan pertambahan panjang dan berat ikan gabus dari perlakuan yang diberikan adalah berbeda nyata, sehingga diperlukan uji lanjut BNT (Tabel 5 dan 6).

Tabel 5. Analisis Beda Nyata Tekecil (BNT) pada panjang ikan gabus

\begin{tabular}{cccc}
\hline Perlakuan & Rerata & Rerata+BNT & Simbol \\
\hline P0 & 8.80 & 9.34 & $\mathrm{a}$ \\
P2 & 9.40 & 9.94 & $\mathrm{~b}$ \\
P1 & 9.80 & 10.34 & $\mathrm{bc}$ \\
P4 & 10.10 & 10.64 & $\mathrm{~cd}$ \\
P3 & 10.50 & 11.04 & $\mathrm{~d}$ \\
\hline
\end{tabular}

Tabel 6. Analisis Beda Nyata Terkecil (BNT) pada berat ikan gabus

\begin{tabular}{cccc}
\hline Perlakuan & Rerata & Rerata+BNT & Simbol \\
\hline P0 & 5.33 & 6.36 & $\mathrm{a}$ \\
P2 & 6.38 & 7.41 & $\mathrm{~b}$ \\
P1 & 6.98 & 8.01 & $\mathrm{bc}$ \\
P4 & 7.75 & 8.78 & $\mathrm{~cd}$ \\
P3 & 8.78 & 9.81 & $\mathrm{~d}$ \\
\hline
\end{tabular}

Keterangan: notasi huruf berbeda menunjukkan adanya perbedaan yang signifikan pada setiap perlakuan

Pengaruh perlakuan dengan penambahan tepung ikan rucah dan udang dalam pakan buatan terhadap pertumbuhan ikan gabus bagi kelangsungan hidup (Survival Rate) tidak menunjukkan pengaruh yang berbeda nyata. Hal ini diduga ada beberapa faktor lain yang dapat memengaruhi kelangsungan hidup ikan gabus di antaranya penyakit, pemeliharaan ikan, pakan, serta kualitas air. Hasil pengamatan terhadap kelangsungan hidup ikan gabus selama 28 hari, didapatkan hasil sebagai berikut (Gambar 3).

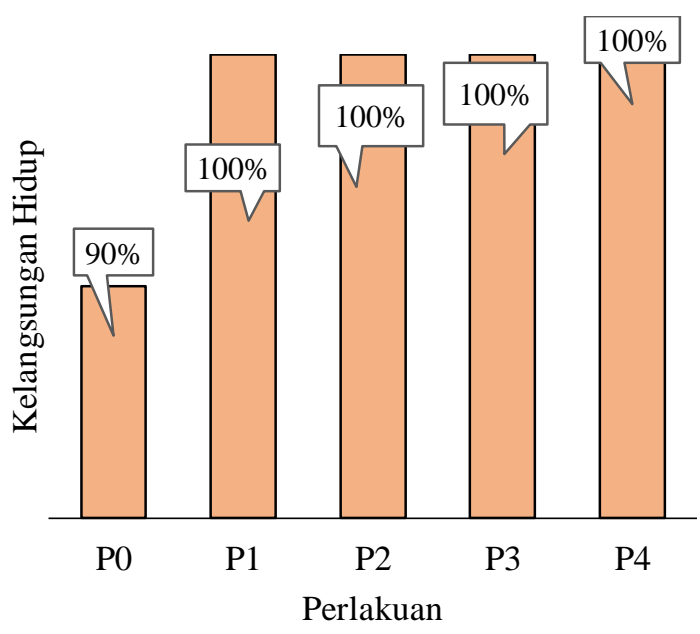

Gambar 3. Kelangsungan hidup ikan gabus

Pengamatan terhadap kualitas air relatif stabil selama 28 hari masa penelitian. Ini dikarenakan pelaksanaan pemeliharaan secara intensif. Dimana pelaksanaan pemeliharaan ikan gabus didalam ruangan, oleh karenanya lebih mudah dikontrol serta kualitas air homogen. Hasil penelitian kualitas air diperoleh $\mathrm{pH}$ antara 7.2-7.7 mg/L serta suhu antara $27-29.5^{\circ} \mathrm{C}$ (Tabel 7).

Tabel 7. Kisaran nilai kualitas air

\begin{tabular}{cccc}
\hline \multicolumn{2}{c}{ Minimum/Maksimum } & $\mathbf{S u h u}^{\mathbf{0}} \mathbf{C}$ & $\mathbf{p H}$ \\
\hline \multirow{2}{*}{ P0 } & min & 27.00 & 7.40 \\
& maks & 29.50 & 7.70 \\
P1 & min & 27.00 & 7.20 \\
& maks & 29.50 & 7.70 \\
P2 & min & 27.00 & 7.20 \\
& maks & 29.50 & 7.70 \\
P3 & min & 27.50 & 7.20 \\
& maks & 29.50 & 7.60 \\
P4 & min & 27.00 & 7.20 \\
& maks & 29.00 & 7.70 \\
\hline
\end{tabular}

Faktor yang berperan penting dalam pertumbuhan ikan gabus adalah pakan, bertambah tingginya kandungan nutrisi dalam pakan ikan berkaitan dengan pertumbuhan ikan yang semakin baik. Laju pertumbuhan ikan gabus berhubungan dengan kandungan nutrisi yang cukup dalam pakan. Selama penelitian, pemberian pakan bertujuan untuk melihat pengaruh nutrisi dengan mengamati pertumbuhan ikan selama waktu yang ditentukan.

Pertumbuhan panjang mutlak yang diamati selama 28 hari didapatkan nilai mutlak paling tinggi yakni sejumlah $3.10 \mathrm{~cm}$, pada perlakuan P3 dengan penambahan tepung ikan rucah dan udang 
pada konsentrasi masing-masing $15 \%$. Welfadiani et al. (2014) yang menyatakan, penambahan tepung udang dengan dosis $20 \%$ pada pakan buatan berpengaruh signifikan terhadap panjang tubuh ikan. Dalam penelitian ini perbedaan konsentrasi yang diberikan tidak mempengaruhi pertumbuhan panjang karena pada perlakuan P3 juga ditambahkan protein yang bersumber dari tepung ikan dengan konsentrasi $15 \%$. Pakan yang baik untuk pertumbuhan panjang ikan gabus, yakni pakan dengan tinggi kandungan proteinnya, karena bila tubuh ikan tidak mendapatkan lemak dan karbohidrat yang cukup maka protein digunakan sebagai sumber energi. Protein di metabolisme oleh ikan untuk memproduksi enzim, hormon, energi dan memperbaiki jaringan sel yang rusak. Khoiriyah (2019), mengatakan metabolisme energi dari protein diawali dengan degradasi protein ke dalam bentuk asam amino.

Meningkatnya pertambahan panjang ikan gabus pada perlakuan P3 dengan penambahan tepung ikan rucah dan udang pada konsentrasi masingmasing sebesar $15 \%$ diduga sebab pakan diberikan dalam dosis yang cukup, sehingga nutrisi pada pakan terpenuhi. Hal ini sesuai dengan Kordi (2009) dalam Aprillia (2018) dimana memaparkan pertumbuhan ikan dipengaruhi salah satunya oleh kandungan nutrisi dalam pakan. Penambahan tepung ikan rucah dan tepung udang dengan dosis masing-masing $15 \%$ bisa memberi pengaruh lebih baik daripada perlakuan lainnya sebab tepung ikan rucah dan udang mempunyai kandungan protein cukup tinggi dalam menunjang proses pertumbuhan. Menurut Yolanda et al. (2013) kandungan protein pada ikan rucah sebanyak $44 \%$ dan menurut Dharmawan (2020), tepung kepala udang memiliki kandungan protein $53.74 \%$. Kedua bahan tersebut memiliki kandungan protein tinggi, sehingga jika dipadukan dengan dosis yang seimbang dapat menghasilkan pakan dengan kandungan protein yang baik.

Pertumbuhan panjang ikan maupun pertumbuhan berat sangat dipengaruhi oleh jumlah kandungan gizi pada pakan. Adanya penambahan tepung ikan rucah dan udang pada pakan buatan mengakibatkan kandungan protein pada pakan meningkat, dengan demikian berpengaruh terhadap pertumbuhan ikan gabus. Didukung oleh Khodijah dkk. (2015) menyatakan bahwa pakan dengan kandungan protein tinggi memiliki nilai biologis yang dapat merangsang lebih besar penimbunan protein daripada protein dengan nilai biologis rendah. Pertumbuhan pada ikan berhubungan dengan ketersediaan pakan yang mengandung protein tinggi. Hal ini disebabkan protein sangat penting dan dibutuhkan untuk pertumbuhan ikan, selain itu jumlah protein juga sangat mempengaruhi pertumbuhan pada ikan.

Perlakuan P3 mengalami pertumbuhan berat yang sangat baik, dapat dilihat pada Gambar 2 dari hari ke 7 sampai ke 28 , sementara pada perlakuan P0 mengalami sedikit peningkatan setiap minggunya. Diduga ini terjadi disebabkan kandungan protein pada pakan yang diberikan rendah, sehingga pertumbuhan ikan baik berat ataupun panjang tidak dapat maksimal. Susunan protein meliputi beberapa asam amino, baik esensial ataupun nonesensial. Tubuh makhluk hidup memerlukan asam amino esensial untuk proses pertumbuhan, tetapi tubuh tidak bisa mensintesis asam amino tersebut. Hal ini menyebabkan ketersediaan asam amino esensial dalam pakan memiliki peran utama dalam meningkatkan pertumbuhan ikan gabus. Uraian ini selaras penyataan dari Cowey (1994) dalam Palinggi (2011) bahwa ikan membutuhkan asam amino untuk mempertahankan proses metabolisme tubuh dan untuk pertumbuhan.

Selain hal tersebut di atas, dari Gambar 2 terlihat pula pertumbuhan berat yang dialami pada perlakuan P1 dan P2 dengan penambahan jenis bahan yang berbeda tetapi dosis yang diberikan sama. Terlihat pada perlakuan P2 dengan penambahan tepung udang $30 \%$ mengalami pertumbuhan yang lebih rendah dibanding perlakuan P1 yaitu penambahan tepung ikan rucah $30 \%$. Diduga ini terjadi karena pakan yang mengandung serat kasar pada perlakuan P2 lebih tinggi daripada serat kasar yang terkandung pada pakan perlakuan P1. Tepung udang yang diolah secara manual memiliki jumlah serat kasar yang tinggi, ini sesuai dengan Palinggi (2011), menyebutkan bahwa tepung kepala udang yang diproses secara sederhana mengandung kitin yang relatif tinggi. Serat kasar yang tinggi akan mengganggu kecernaan protein pakan ikan, hal inilah yang menyebabkan pertumbuhan ikan gabus rendah.

Kelangsungan hidup ikan dapat dipengaruhi oleh kondisi lingkungan sekitar dan ketersediaan pakan. Kuantitas dan kualitas pakan yang cukup dan baik serta didukung oleh kondisi lingkungan yang baik pula, maka sangat mendukung kelangsungan hidup ikan gabus. Yuniarso (2006) dalam Aprillia (2018), memaparkan bahwa tingginya persentase kelangsungan hidup (Survival rate) dipengaruhi beberapa faktor di antaranya penanganan manusia, kemampuan organisme 
dalam beradaptasi, umur, penyakit, kepadatan penduduk, serta competitor.

Persentase kelangsungan hidup ikan gabus selama 28 sekitar 90-100\%. Hasil penelitian memperlihatkan tidak terdapat pengaruh nyata terhadap adanya penambahan campuran tepung ikan rucah dan udang dalam pakan buatan terhadap kelangsungan hidup ikan gabus. Selama pemeliharaan didapatkan data, tingkat kelangsungan hidup termasuk dalam golongan baik. Mulyani (2014), memaparkan tingkat kelangsungan hidup (SR) $<30 \%$ tidak baik, 30$50 \%$ tergolong sedang, serta $\geq 50 \%$ tergolong baik.

Mengacu pada analisis parameter untuk pengukuran kualitas air didapatkan bahwa ikan gabus ada pada lingkungan yang baik untuk berkembang dan tumbuh. Lingkungan termasuk suhu perairan berkisar $26.5-31.5^{\circ} \mathrm{C}$ dan tingkat keasaman $(\mathrm{pH})$ untuk ikan gabus khusus marga Channa mampu hidup diperairan yang memiliki nilai $\mathrm{pH}$ 7-8.

Air yang digunakan pada media pemeliharaan perlu dijaga kualitasnya. Pelaksanaan pengukuran air, yakni pada $\mathrm{pH}$ dan suhu yang dilakukan selama perlakuan, dengan hasil masih ada dalam batasan yang baik untuk pertumbuhan ikan gabus. Air yang dipakai berasal dari PDAM yang sebelumnya sudah diendapkan dan diaerasi, guna meningkatkan pertumbuhan yang baik bagi ikan. Penyiponan atau penggantian air dilakukan pula setelah proses pengukuran berat serta panjang ikan dengan membuang $50 \%$ dari total air

\section{KESIMPULAN}

\section{Simpulan}

Pertambahan panjang dan berat total ikan uji paling baik pada perlakuan P3 yaitu dengan nilai berat mutlak yaitu $6.60 \mathrm{~g}$ serta panjang mutlak yaitu $3.10 \mathrm{~cm}$, dengan penambahan tepung ikan rucah dan udang masing-masing $15 \%$.

\section{Saran}

Perlu dilakukan uji kandungan nutrisi pakan untuk mengetahui kuantitas nutrisi yang terkandung pada campuran pakan tersebut.

\section{DAFTAR PUSTAKA}

Akbar, C., Utomo, D. S. C., Hudaidah, S., \& Setyawan, A. (2020). Manajemen waktu dan jumlah pemberian pakan dalam meningkatkan pertumbuhan dan sintasan ikan gabus, Channa striata (Bloch, 1793). Journal of Aquatropica Asia, 5(1), 1-9.

Aprillia, A. C. (2018). Pengaruh Penambahan Campuran Tepung Limbah Ikan Tuna pada Pakan Komersil Terhadap Pertumbuhan Ikan Lele (Clarias sp.). Skripsi. Universitas Sumatera Utara.

Dharmawan, B. (2020). Usaha Pembuatan pakan Ikan Konsumsi. Pustaka Baru Press: Yogyakarta.

Effendi, M. I. (1997). Biologi Perikanan. Yayasan Pustaka Nusantara: Yogyakarta.

Khodijah, D., Rachmawati, D., \& Pinandoyo. (2015). Performa Pertumbuhan benih ikan lele sangkuriang (Clarias gariepinus) melalui penambahan enzim papain dalam pakan buatan. Journal of Aquaculture Management and Technology, 4(2), 35-43.

Khoiriyah, D. N. (2019). Pengaruh Pemberian Pakan Alternatif Limbah Ikan Asin dan Tepung Kedelai Terhadap Pertumbuhan Ikan Lele Dumbo (Clarias gariepinus). Skripsi. Universitas Islam Negeri Raden Intan Lampung.

KKP. (2020). Langkah KKP kembangkan industri budidaya ikan gabus sebagai komoditas unggul berbasis lokal. https://kkp.go.id/artikel/23431langkah-kkp-kembangkan-industri-budidayaikan-gabus-sebagai-komoditas-unggulanberbasis-lokal. Kementrian Kelautan dan Perikanan Republik Indonesia. Diakses pada tanggal 22 Maret 2021.

Kusuma, M. S., Ade, D S., \& Yulisman. (2017). Kelangsungan hidup dan pertumbuhan benih ikan gabus (Channa striata) yang diberi ikan rucah berbeda sebagai pakan. Jurnal Akuakultur Rawa Indonesia, 5(1), 13-24.

Maulidin, R., Muchlisin, Z. A., \& Muhammadar, A. A. (2016). Pertumbuhan dan pemanfaatan ikan gabus (Channa striata) pada konsentrasi enzim papain yang berbeda. Jurnal Ilmiah Mahasiswa Kelautan dan Perikanan Unsiyah, 1(3), 280-290.

Muliati, W. O., Kurnia, A., \& Astuti, O. (2018). Studi perbandingan pertumbuhan ikan gabus (Channa striata) yang diberi pakan pellet dan keong mas (Pomacea canaliculata). Media Akuatika, 3(1), 72-580.

Mulyani, Y. S., Yulisman., \& Mirna, F. (2014). Pertumbuhan dan efisiensi pakan ikan nila (Oreochromis niloticus) yang dipuasakan secara periodik. Jurnal Akuakultur Rawa Indonesia, 2(1), 01-12. https://doi.org/10.36706/jari.v2i1.1958. 
Palinggi, N. N., \& Usman. (2011). Pengaruh pemberian tepung kepala udang dalam pakan ikan beronang, Siganus guttatus. Prosiding Forum Inovasi Akuakultur, 979-984.

Sari, I. P., Yulisman., \& Muslim. (2017). Laju pertumbuhan dan efisiensi pakan ikan nila (Oreochromis niloticus) yang dipelihara dalam kolam terpal yang dipuasakan secara periodik. Jurnal Akuakultur Rawa Indonesia, 5(1), 45-55. https://doi.org/10.36706/jari.v5i1.5807.

Sandri, T. D. (2018). Pengaruh Campuran Tepung Kepala Udang, pada Pakan Komersil Terhadap Pertumbuhan Ikan Nila (Oreochromis niloticus). Skripsi. Universitas Sumatera Utara.

Welfadiani, J., Helmizuriyani., \& Elfachmi. (2014). Campuran tepung kepala udang pada pakan buatan terhadap pertumbuhan ikan maskoki (Carassius auratus). Fiseries, 3(1), 813.

Winarni, B. (2019). Pengaruh Pemberian Pakan Dengan Penambahan Ampas Kelapa Terfermentasi Rhizopus oryzae Terhadap Pertumbuhan Ikan Patin (Pangasius djambal). Skripsi. Universitas Sanata Dharma. Yogyakarta.

Yolanda, S., Santoso, L., \& Harpeni, E. (2013). Pengaruh subtitusi tepung ikan dengan tepung ikan rucah terhadap pertumbuhan ikan nila gesit (Oreochromis niloticus). Jurnal Rekayasa dan Teknologi Budidaya Perairan, 1(2), 95-100.

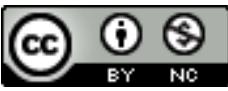

This work is licensed under a Creative Commons Attribution-NonCommercial 4.0 International License 